\title{
Light Conditions, Soil Moisture, and Vegetation Cover in Artificial Forest Gaps in Western Hungary
}

\author{
Tamás KOLLÁR* \\ Department of Ecology and Silviculture, Forest Research Institute, \\ National Agricultural Research and Innovation Centre, Sárvár, Hungary
}

\begin{abstract}
One of the greatest challenges of continuous cover forest management is to find a suitable gap size in a given forest stand that will help the regeneration of economically significant tree species, and possibly control competitor species. This paper summarizes the results of a two-year intensive mapping of various bearing artificial gaps at two sites in western Hungary: a sessile-oak-hornbeam and a Turkey oak forest. Light conditions and soil moisture were measured in the gaps as abiotic variables. Hemispherical photography and a Field Scout TDR 300 Soil Moisture Meter were used. Vegetation cover as well as quantity and height of the regeneration were measured as biotic variables. There are significant differences between the middle of a gap and the closed canopy forest stands. The maximum light intensity below the canopy shows a slight northward dislocation. Correlation analysis results showed that a gap's slight, northward irradiation surplus effected soil moisture, regeneration heights, and total vegetation cover less than a gap's real shape and size, ergo, its openness did.
\end{abstract}

gap / continuous cover forest management / light conditions / soil-moisture / regeneration / plant cover

Kivonat - Talajnedvesség, fényviszonyok és a vegetáció borításának térbeli változása mesterséges lékekben a Nyugat-Magyarországon. A folyamatos erdőborítást biztosító erdőgazdálkodás egyik legjelentősebb kihívása egy adott erdőállomány esetében megtalálni azt a megfelelő lék méretet, amely segíti a gazdaságilag értékes fafajok felújulását, azonban lehetőség szerint korlátozza a kompetitorokat. A tanulmány összefoglalja egy két éves időtartamú intenzív felvételezés eredményeit különböző tájolású mesterséges lékekben két kísérleti területen, Nyugat-Magyarországon: egy gyertyános-kocsánytalan tölgyes és egy cseres-tölgyes erdőrészletben. A lékekben fényviszony és talajnedvesség mérések történtek, mint abiotikus változók. Hemiszférikus fényképezést és Field Scout TDR 300 talajnedvesség mérőt használtunk. Biotikus változóként vegetációborítást, az újulat mennyiségi és magassági méréseit végeztük el. Szignifikáns különbségek találhatóak a lék középpontja és a zárt lombozató erdőállomány között. A fénybesugárzás maximuma a lombkorona alatt csekély északi irányú eltolódást mutat. Az korreláció vizsgálati eredmények kimutatták, hogy a lékek csekély északi irányú besugárzástöbblete kisebb hatással bír a talajnedvességre, a csemetemagasságra és a teljes növényborítottságra, mint a lék valós alakja és mérete, tehát annak nyitottsága.

lék / folyamatos erdőborítást biztosító erdőgazdálkodás / fényviszonyok / talajnedvesség / újulat / növényborítás

\footnotetext{
*Corresponding author: kollart@erti.hu; H-9600 SÁRVÁR, Várkerület 30/a, Hungary
} 


\section{INTRODUCTION}

A major question in Hungarian forest management is "how to transform a clear cutting forest to a selection cutting forest" (Koloszár 2005). The selection cutting forest is a special forest stand shape (forest scape) established by prolonged continuous selection cutting (harvesting or intervention of stems) (Solymos 2000). Adequate environmental parameters such as light and water are indispensable for seedling growth.

There is a great debate in Hungarian silviculture literature about which woody species are suitable for selection cutting and which are suitable for silviculture under continuous forest cover. At the beginning of the twentieth century, Roth (1935) wrote about the light demands of woody species and that light-demanding and shade-tolerant species can be differentiated. Oaks are described as light-demanding species but with significant differences amongst the various oak species. Koloszár (2005) states that only shade-tolerant species, such as European silver fir (Abies alba), Norway spruce (Picea abies) and European beech (Fagus sylvatica) are suitable for selection cutting The regeneration of light-demanding oaks theoretically contradicts the decreased light quantity of gaps, but in many cases the idea of selection cutting silvicultural system overwrites these (Pro Silva 1999, Bodonczi et al. 2006, Csépányi 2008, Reininger 2010). Csépányi (2008) shows several examples for oak regeneration and proposes how to choose the required gap size, shape, and bearing. Gálhidy et al. $(2005,2006)$ makes intensive studies in beech stands. Török (2006) fully assays the methods of exposure-orientated regeneration in beech forests; however, such a detailed work does not exist for oaks yet. A law passed in 2009 requires forest managers to use gaps for natural regeneration in every type of forest, even in oak dominated forests where scientific research has not yet been completed and established.

Mountain areas with beech and coniferous species are highly representative in international silviculture literature (Clinton 2003, Gagnon et al 2004, Page - Cameron 2006, Naaf - Wulf 2007, Ritter et al 2005, Cater et al 2014). Tropical forests are also frequently studied with basic gap dynamics (Brown 1996, Van Dam 2001, d'Oliveira - Ribas 2011). Oak species are less studied, especially in mixed forests (Aikens et al 2007, Petritan et al. 2013).

Since it is difficult to express the light-demand of tree species, finding more accurate indices than gap size is required. The conventional subjective canopy closure estimation cannot be used in the case of gaps because a regular gap is theoretically open, while the surrounding forest stand has the average closure of the forest sub-compartment; therefore, it is reasonable to use other measurements. Describing a gap by its size measured on the ground cannot provide adequate answers about the light conditions dominating the gap (Kollár 2013). Studies of light conditions using hemispherical photography have their history already back in the age of analogous cameras (Frazer et. al. 1999, Brunner 2002), but photography techniques and digital processing have advanced greatly since then.

Soil moisture is changing and the gaps become watered when gaps opened in closed forest stands. Soil moisture content variability is high between the gap centre and the surrounding closed forest stand (Van Dam 2001). More measurements are required to show the variability of soil moisture at the temporal and spatial scale. Extensive studies of gap regeneration and its hydrological consequences are conducted in Hungary mostly in beech stands, which are preferred for continuous-cover forest management purposes. Manninger (2008) states that there are differences in absolute value of soil moisture in the gaps and in the surrounding closed forest, but the directions and values of change are similar. Gálhidy et al. (2006) claim there are no significant soil moisture differences in a small or large gap, but the values in a large gap are more diverse. Moreover, soil moisture was higher in gaps than it was under a closed stand. The presence of soil moisture indicator herbaceous species is generally a good indicator for soil moisture determination in the absence of instrumental measurements. Tobisch (2010) said that 
the height of the tallest sessile oak and hornbeam seedlings was related mainly to the cover of soil moisture indicator plants.

The research aim is to discover whether there are differences between closed canopy control parcels and young, early-staged gaps and gap regions. This paper was a primer study of a long duration research project where the development of artificial gaps has been examined in reasonable periods. The gaps will be increased in the future, and further comparisons could be studied with greater gap sizes, and developed regeneration.

Our questions are the following:

- Are there significant differences in soil moisture, regeneration, or herb coverage between the brighter gaps and the closed canopy control plots?

- Have the gaps become watered and affected regeneration and vegetation coverage?

- Are there correlations between the measured abiotic (light and soil moisture) and biotic (regeneration, plant cover) factors?

\section{MATERIALS AND METHODS}

\subsection{Research sites}

The research took place in Central Europe, in Vas County in western Hungary. Two sites were involved (Table 1, Figure 1) and the temporal range covered the vegetation period of 2013 and 2014. The study sites are flat; gaps were opened in each sub-compartment in 2011. There are three parcels in both sites, each with an area of 0.25 ha $(50 \times 50$ metres $)$ including two similarsized artificial forest gaps and one control area with closed canopy. The elliptical gaps are about one-tree height long and half-tree height wide (approximately $30 \times 15$ meters), with one orientated north-south, and the other east-west.

Table 1. Research sites (H: Average Height, D1.3: Average diameter at breast height, $N$ : Number of Stems per Hectare, at the Bejcgyertyános 13 A site, for sessile oak's data first, than hornbeam's data)

\begin{tabular}{|c|c|c|c|c|c|c|c|c|}
\hline \multirow{3}{*}{$\begin{array}{l}\text { Forest sub- } \\
\text { compartment }\end{array}$} & \multirow{3}{*}{$\begin{array}{l}\text { Forest stand } \\
\text { type }\end{array}$} & Age & $\mathrm{H}$ & $\mathrm{D}_{1.3}$ & $\mathrm{~N}$ & \multirow{3}{*}{ Soil type } & \multirow{3}{*}{\multicolumn{2}{|c|}{ Hydrology }} \\
\hline & & \multicolumn{4}{|c|}{ in 2011 (gap opened) } & & & \\
\hline & & years & $\mathrm{m}$ & $\mathrm{cm}$ & $\mathrm{n} / \mathrm{ha}$ & & & \\
\hline $\begin{array}{l}\text { Bejcgyertyános } \\
13 \text { A } \\
\left(\mathrm{N} 47^{\circ} 11.304^{\prime},\right. \\
\left.\text { E17 } 0.626^{\prime}\right)\end{array}$ & $\begin{array}{l}\text { Sessile oak- } \\
\text { hornbeam }\end{array}$ & 81 & $\begin{array}{l}26.0 \\
17.5\end{array}$ & $\begin{array}{l}33 \\
11\end{array}$ & $\begin{array}{l}302 \\
172\end{array}$ & $\begin{array}{l}\text { Lessivated } \\
\text { brown forest soil } \\
\text { (Vertisol) }\end{array}$ & $\begin{array}{l}\text { Water- } \\
\text { losing sites }\end{array}$ & Loam \\
\hline $\begin{array}{l}\text { Vép } 32 \mathrm{D} \\
\left(\mathrm{N} 47^{\circ} 13.667^{\prime},\right. \\
\left.\text { E16 }^{\circ} 47.307^{\prime}\right)\end{array}$ & Turkey oak & 67 & 26.4 & 28 & 459 & $\begin{array}{l}\text { Surface water gley } \\
\text { brown forest soil } \\
\text { (Vertisol) }\end{array}$ & $\begin{array}{l}\text { Water- } \\
\text { losing sites }\end{array}$ & Loam \\
\hline
\end{tabular}

In each gap and the surrounding closed forest stand, 41 grid points were set in a regular pattern, while in the control area 16 grid points were set (Figure 2). The grid points are 5 meters apart in the middle of the gaps, and 10 meters apart at the sides and under closed canopy in order to get a similar number of samples. During data processing, grid points in the parcels were categorised into three gap regions: middle of the gap (Gap, $n=11$ ), sides of the gap (Sides, $\mathrm{n}=12$ ), and under closed canopy (Closed, $\mathrm{n}=18$ ). 


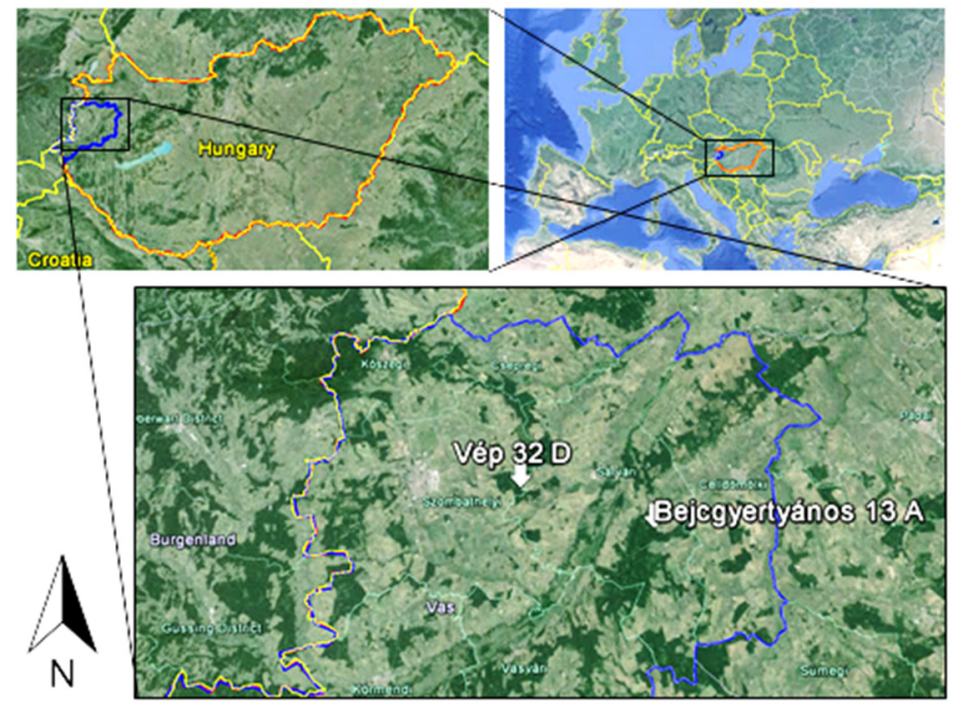

Figure 1. Research sites, Vas County, western Hungary, Central Europe

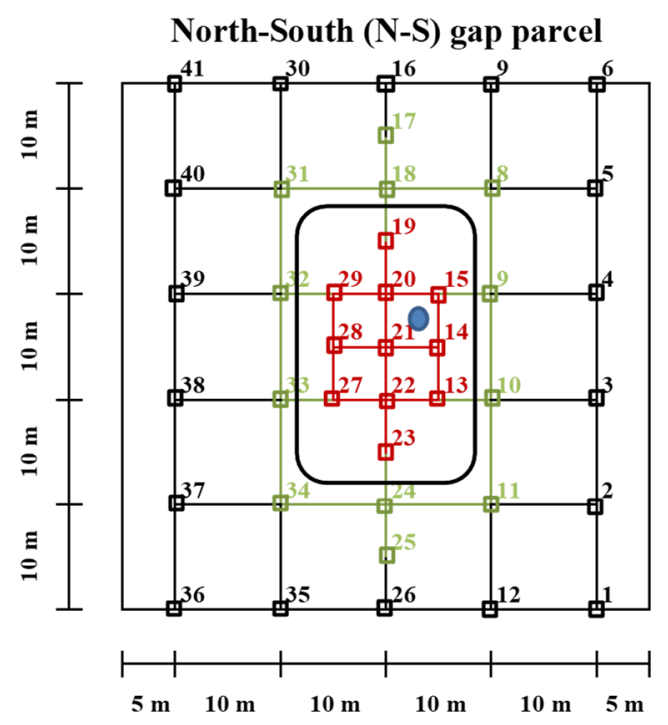

East-West (E-W) gap parcel

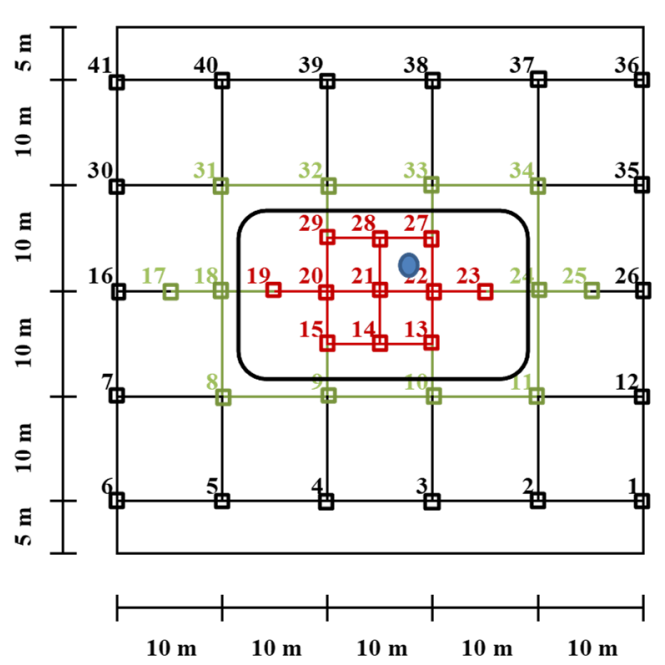

Closed canopy (Control) parcel

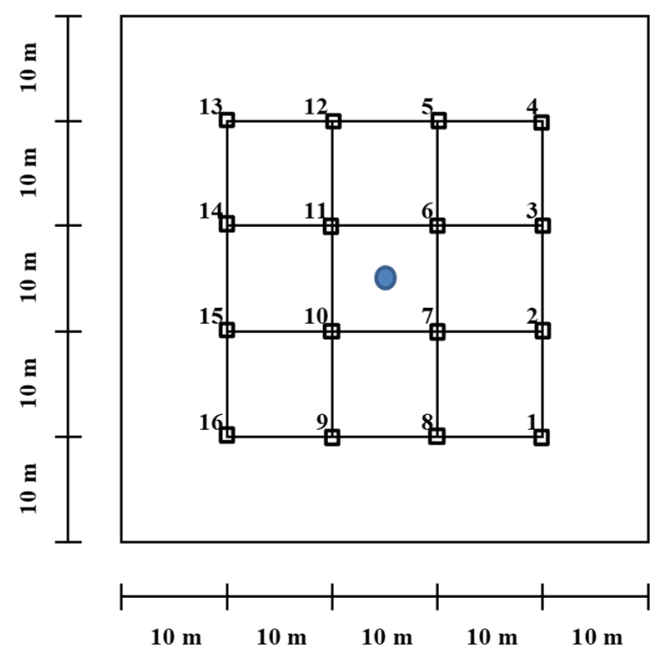

- Rain gauges

- Gap / closed canopy edge 1 Under closed canopy grid points 8 Sides of the gap grid points 13 Middle of the gap grid points

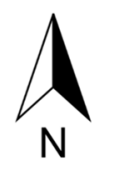

Figure 2. Experimental designs of the two gaps and control parcel in the research sites 


\subsection{Field methods}

\subsubsection{Light condition measurements}

A Sony NEX-7 24 MP DSLR camera with calibrated fish-eye lens in automatic program settings was used in the experiment. The camera was inside a levelling mount with North Finder, in a $170 \mathrm{~cm}$ high position. Two sets of hemispherical photos were taken at every grid point of the sites, during sunny sky conditions at the end of August 2013 and 2014. Photos were evaluated with WinSCANOPY 2013a software (Guay 2012). As input data, the geographical position (GPS coordinates), altitude, height of the camera, slope, aspect, time of the growing season, and the orientation of the photo are required for photo analysis. It is necessary to have sharp, high-resolution photos in order to differentiate the celestial sphere from the vegetation (or other covering objects). Interactive pixel classification was used to separate sky and covered pixels. With this method, sun spots can be eliminated; therefore, photos taken in imperfect sky conditions can be used.

In the study, openness and total site factor data were used from photo evaluation. Openness is the fraction of open sky (unobstructed by vegetation) in a specified region of the real canopy above the lens. It is similar to the canopy closure used by foresters, but hemispherical photography monitors sideward irradiation also. The total site factor is the fraction of total (direct and diffuse) photosynthetically active flux density under and over canopy average for the growing season (Guay 2012). In the evaluation, the growing season was set as it lasted from $1^{\text {st }}$ April to $30^{\text {th }}$ September. Therefore, the irradiation of the entire growing season can be estimated by taking one photo with maximum leaf area as the program computes the irradiation at all hours of all days in the growing season. Using all photos of a parcel, spatial models were made.

\subsubsection{Soil moisture measurements}

Field Scout TDR 300 Soil Moisture Meter was used in the research (Spectrum Inc., 2009). Data collection mode was set to default calibration for standard soils. During measurement campaigns, four repeats of measurements were taken at each grid point. Depending on weather conditions, measurements were taken between one- to two-week periods. Between April and October 2013, 23 measurement campaigns were undertaken in 2013 and 16 in 2014. We used different rod lengths $(20 \mathrm{~cm}, 12 \mathrm{~cm}$, and $7.6 \mathrm{~cm})$ at the beginning of the research. The most reliable was $7.6 \mathrm{~cm}$; therefore, we used this as the standard (see Appendix).

\subsubsection{Regeneration measurements and cover estimations}

In each year of the study between $11^{\text {th }}$ August and $19^{\text {th }}$ September, one set of regeneration measurements and cover estimations (abundance) were made at every grid point in the parcels. Seedlings of every tree species were counted in four $1 \mathrm{~m}^{2}$ quadrants. The heights of the tallest seedlings per species were measured in all quadrants. Cover estimations of the dominant species were taken by visual assessment in these total 4 quadrant areas with an accuracy level of $1 \%$ to $5 \%$, then $5 \%$ accuracy with higher coverage values. In this paper, only total vegetation coverage was examined, which is the sum of all species cover. It is also equal to $100 \%$ minus the vegetation non-covered ground.

\subsubsection{Statistical analyses and visualisation}

Spatial changes of measured variables are visualised with categorised box and whisker plots. Categorised variables were the sites, bearing of the gaps or control, and gap regions inside a parcel. T-tests were used to find significant differences between variables within a parcel.

Spatial distributions of the data were presented with 3D contour plot diagrams, which were created with the least squares fit options and minimum stiffness. 
In the case of soil moisture measurements, the first step of the analyses was to standardize the soil moisture data that came from different soil depths (see Appendix). Demonstrating the temporal change of soil moisture, average values of daily soil moisture data were presented in diagrams, trend lines were fitted, and $\mathrm{R}^{2}$ calculated to find out how well the model fits the data (Figure 5).

Relationships of individual data were searched using a Pearson Product-Moment correlation matrix. For statistics and visualisation, Microsoft Excel 2010 and StatSoft Statistica 2000 programs were used.

\section{RESULTS AND DISCUSSION}

\subsection{Spatial changes of light conditions}

In Figure 3, light condition differences in gap regions can be seen for year 2013. Light conditions in 2014 showed slightly higher data. T-tests $(\mathrm{p}<0.05)$ for openness and also total site factor in 2013 and 2014 show less than $0.3 \%$, but significant differences in average.

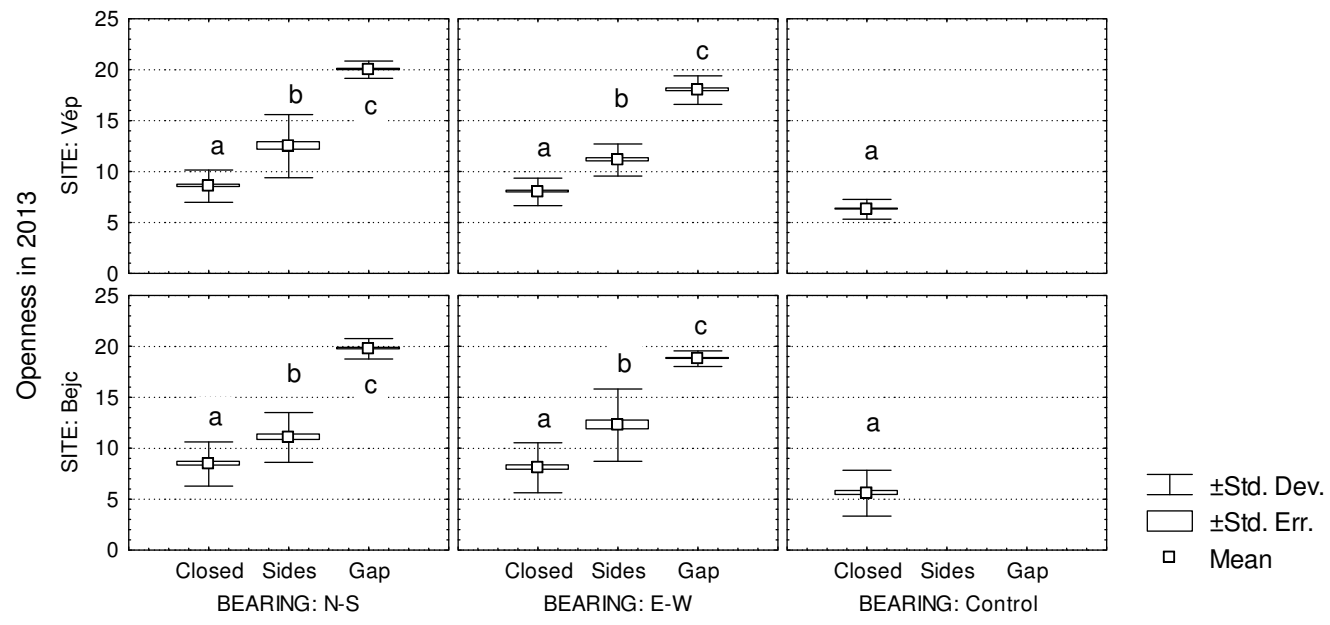

(a)

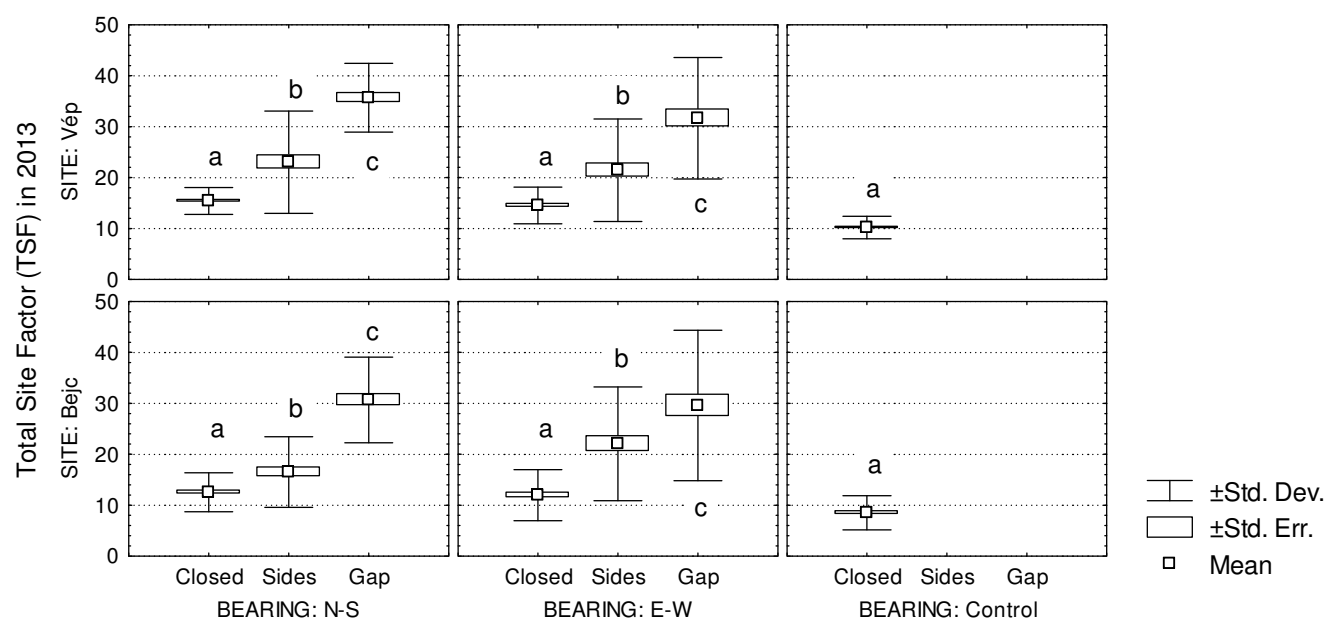

(b)

Figure 3. Openness (a) and total site factor (b) values in 2013,

different letters indicate significant differences $(p<0.05)$ between means inside a parcel 
It is nearly impossible to make gaps that are exactly the same size even in artificial opened gaps. There are traceable differences between the sites, and between gaps within the sites (Figure 3). In the case of openness, the gap regions show apparent differences, but the openness values under closed canopy areas were significantly different compared to the control parcel. This means that the parcels should be greater and have denser grid points to model the whole range of canopy closure from the middle of the gap to the closed canopy forest stand.

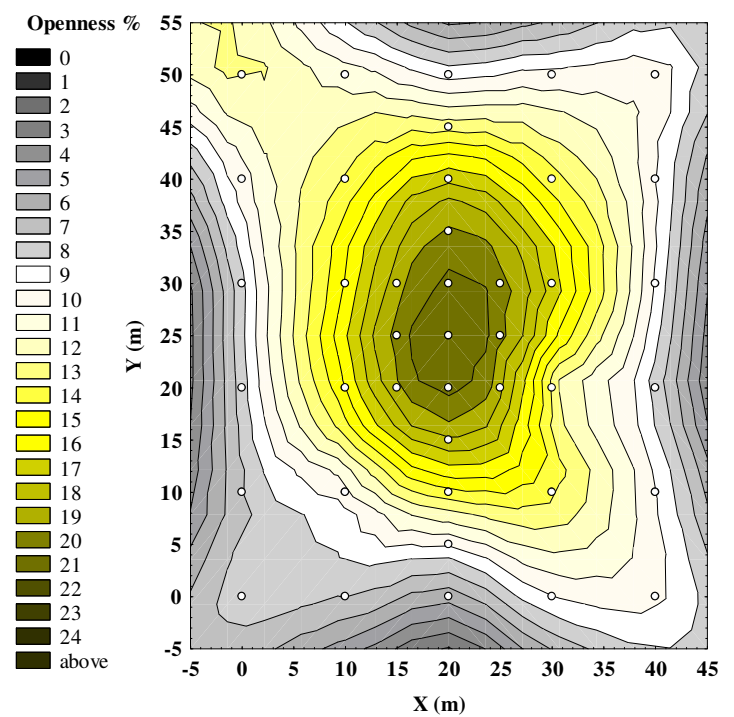

(a) Openness \%

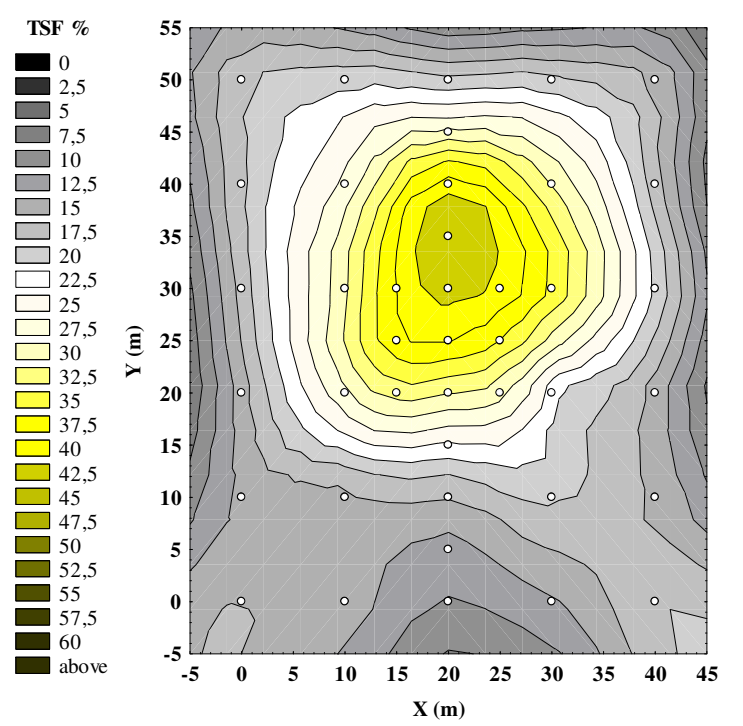

(b) Total Site Factor \%

Figure 4. Vép 32/D, north-south gap Openness (a) and total site factor (TSF) (b) in 2013

Figure $4(a)$ shows the symmetry of the gap in a 3D contour plot diagram as the viewer moves from the gap centre towards the closed canopy. The effects of nearby gaps are visible at the corners. Nearby gaps are also too close to each other and, thus, affect each other. In Figure $4(b)$, the maximum light intensity below the canopy shows a slight northward dislocation. This light effect is similar to what Csépányi (2008) noted. A similar dislocation occurred in the case of a gap with an east-west orientation. It is important to note that even the most illuminated area within the investigated gaps recorded only about $40-50 \%$ of the above canopy light quantity, and this decreases rapidly when nearing the closed forest canopy. At the sides of the gap, about $20-30 \%$ of the above canopy light reaches the surface, while under closed canopy it is only 10$15 \%$.

\subsection{Temporal and spatial changes of soil moisture}

The two vegetation periods had a great precipitation variance, which had a big influence on soil moisture. Precipitation was measured in the six parcels with rain gauges during the research. There was an average of $250 \mathrm{~mm}$ of precipitation in Vép and $319 \mathrm{~mm}$ in Bejcgyertyános from the beginning of April to the end of October 2013; however, in same period in 2014, precipitation was $466 \mathrm{~mm}$ in Vép and $525 \mathrm{~mm}$ in Bejcgyertyános.

In Figure $5(a-b)$, trend lines show the modelled temporal changes of soil moisture. These trend models were divided into three periods a year: the beginning of vegetation season, drought period, and the end of vegetation season; the periods' average soil moisture values were presented with horizontal lines. 


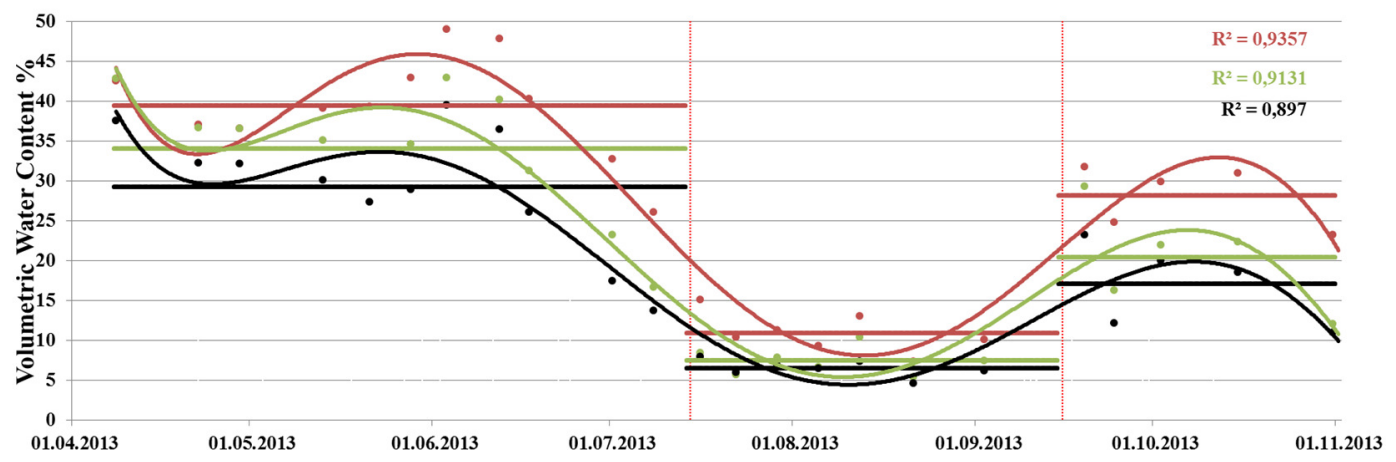

(a) 2013

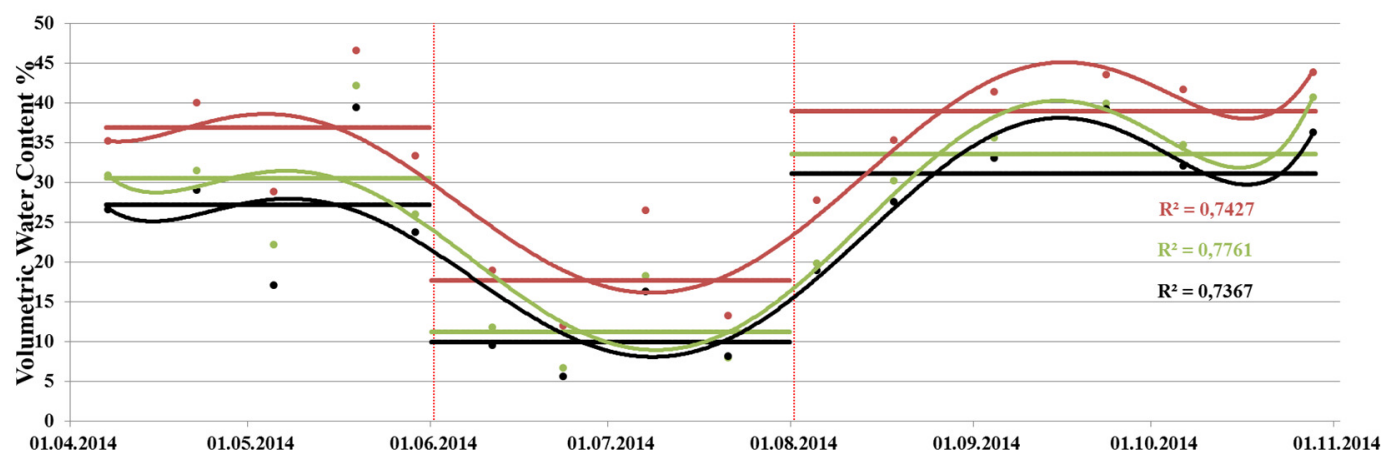

(b) 2014

Figure 5. Vép 32/D, north-south gap average soil moisture

(Volumetric Water Content) data in 2013 (a) and in 2014 (b)

(middle of the gap: red line, sides of the gap: green line and under closed canopy: black line)

The soil moisture fluctuation is marked in the two different years (Figure $5(a-b)$. In 2013, an extended drought period was observed between the middle of July and the middle of October. Then in the winter, the soil could not reach the saturated phase; consequently, the 2014 vegetation season began in less moist conditions. In 2014, June was the only virtually rainless month and the soil moisture dropped during this time. After that short dry period, soil moisture increased rapidly. There was no real so-called drought period, while the decreased soil moisture phase started one-and-ahalf-months earlier than the previous year's drought and lasted the same two months. By the beginning of September, soil moisture reached its maximum as it had at the beginning of 2013.

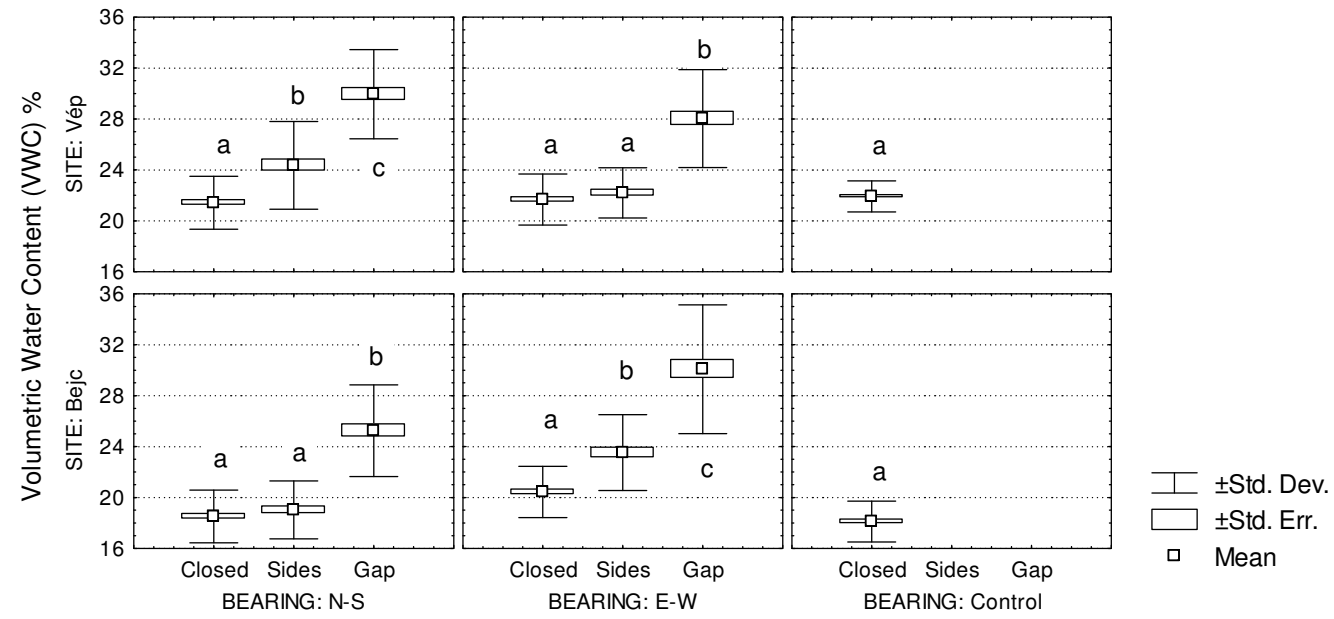

Figure 6. Average soil moisture (Volumetric Water Content) data of 2013 and 2014, different letters indicate significant differences $(p<0.05)$ between means inside a parcel 
There are differences in the absolute values of soil moisture between the two sites and also between various gaps (Figure 6), but the tendencies are the same. Manninger (2008) stated similar results in beech stands. The gaps have become watered. For all samples in the research period, the mean value of Volumetric Water Content (soil moisture) in the vegetation period in the sites is about 6 percentage points higher in the middle of a gap (29\%) than at the sides of it $(23 \%)$. The soil moisture is a further 2 percentage points lower under closed canopy $(21 \%)$. It is also evident that standard deviations are decreasing as measurements move from the middle of a gap to under closed canopy. This shows the same results as Gálhidy (2006), who wrote that the soil moisture values are more diverse in a gap.

The differences in the absolute value of average soil moisture between the north-south and east-west oriented gaps cannot be explained yet, but tendencies are similar.

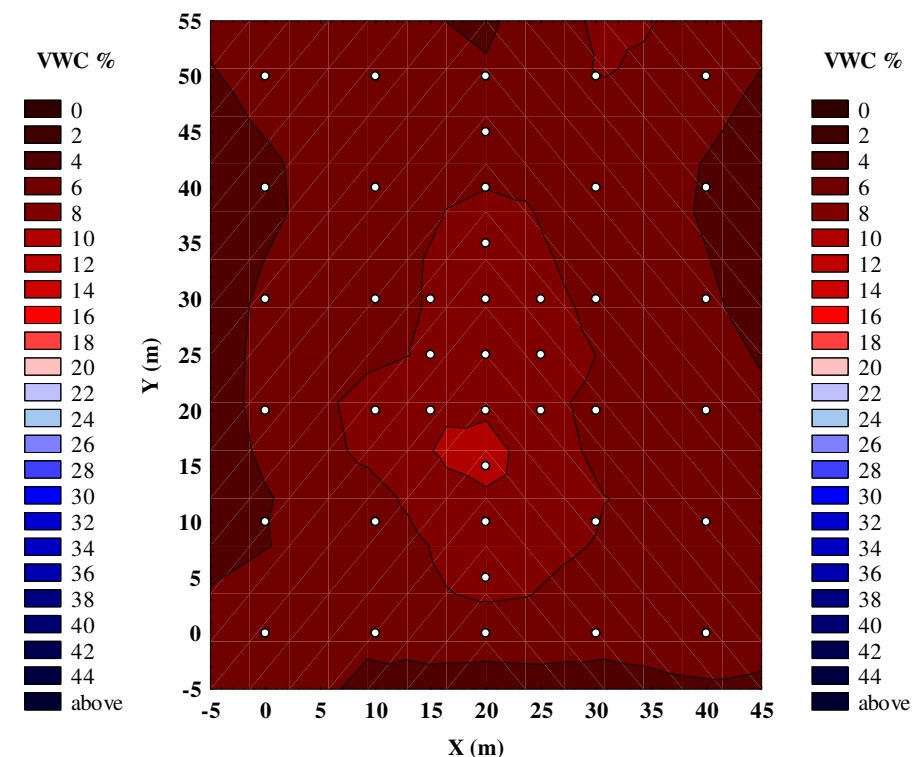

a) 21.08 .2013

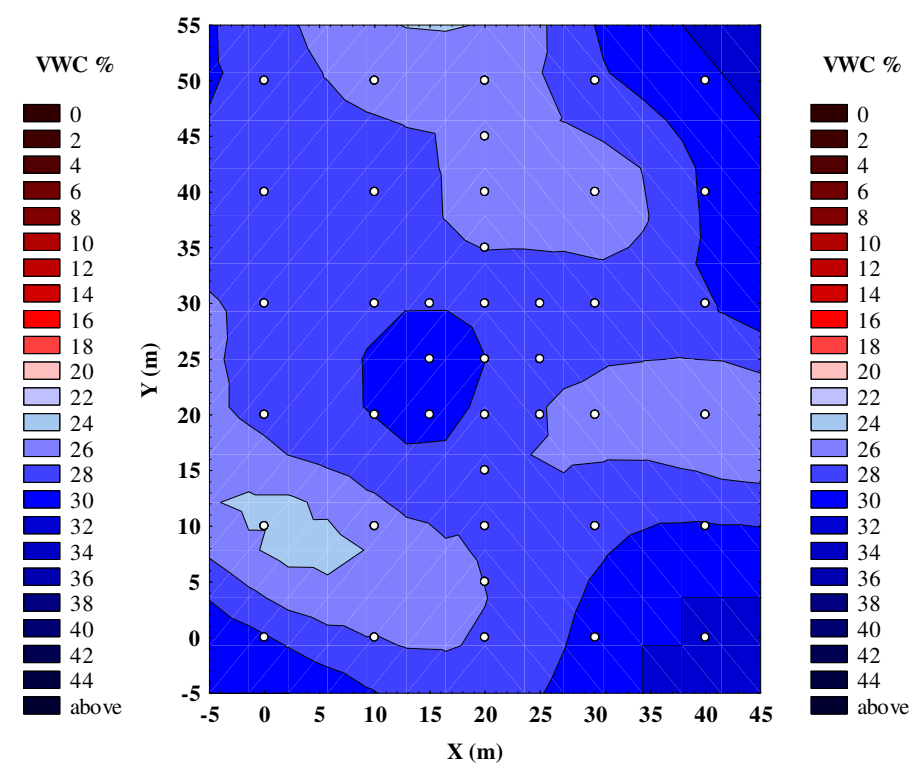

(c) 22.04 .2014

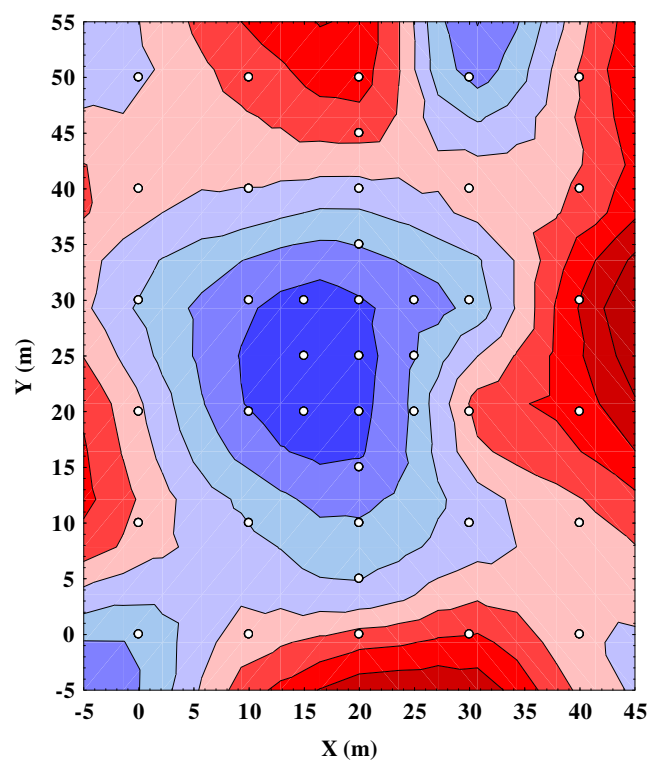

(b) 15.10 .2013

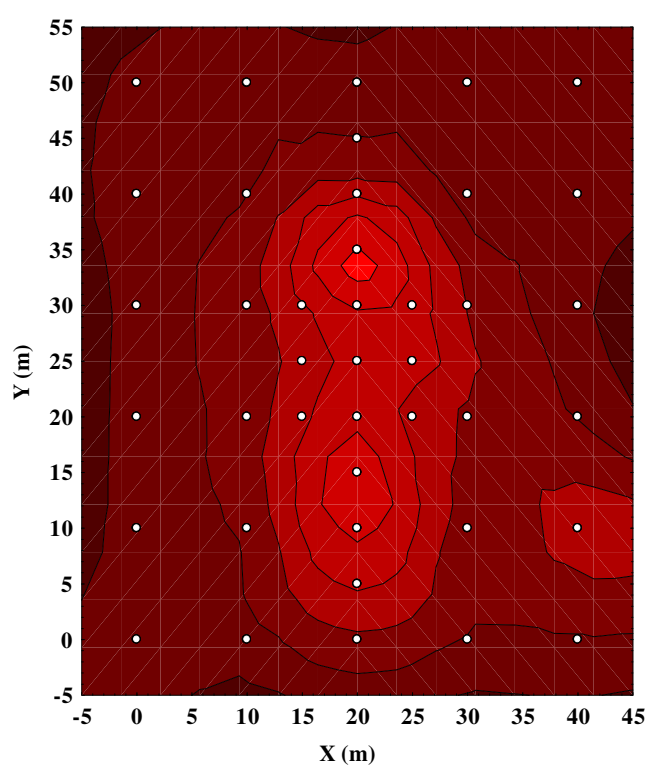

(d) 23.06.2014

Figure 7. Vép 32/D, north-south gap

21.08.2013: the driest soil phase (a), 15.10.2013: a medium moist soil phase (b), 22.04.2014: moist soil phase (c), 23.06.2014: the driest soil phase in 2014 (d). 
The spatial changes of soil moisture can be exemplified in 3D contour plot diagrams. In Figure $7(a, b, d)$ the moister phase of the middle of a gap has clearly been drawn; difference remains in the driest periods, too (a). Close to the saturation of the soil in spring and fall, these differences can decrease or almost disappear $(c)$. The water uptake of the still standing mother stand's rooting area has a greater impact on the spatial changes of soil moisture in a gap and its surroundings than the gap's light conditions, as it seemed in the case of total site factor. These moist phases cannot be compensated by greater amount of sunlight in the monitored gap size.

\subsection{Regeneration measurements}

There were no significant regenerations in the Bejcgyertyános site; only very few $\left(0.88 \mathrm{n} / \mathrm{m}^{2}\right.$ in $2013,0.44 \mathrm{n} / \mathrm{m}^{2}$ in 2014) sessile oak (Quercus petraea) seedlings were found in the gaps. In the Vép 32 D site, a great number $\left(5.38 \mathrm{n} / \mathrm{m}^{2}\right.$ in $2013,5.31 \mathrm{n} / \mathrm{m}^{2}$ in 2014) of Turkey oak (Quercus cerris) seedlings were found during the two-year period. Figure 8 shows the average height of seedlings in 2014.

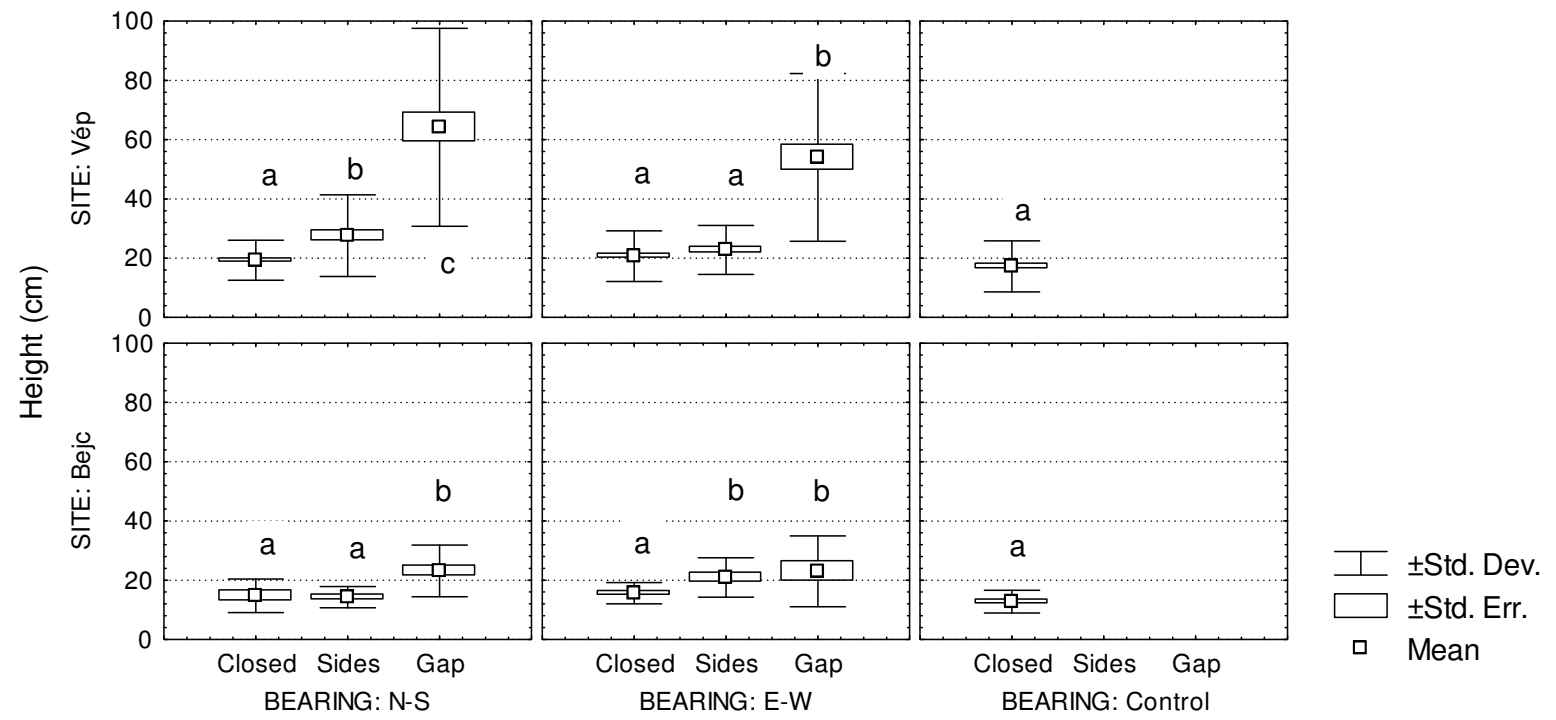

Figure 8. Height of seedlings in 2014

(Quercus cerris in Vép site, Quercus petraea in Bejcgyertyános site),

different letters indicate significant differences $(p<0.05)$ between means inside a parcel

The number of seedlings was similar (not significantly more seedlings than in 2014) at the Vép site in 2013, but the height of the seedlings was significantly lower. In 2013, the height of Turkey oak (Quercus cerris) seedlings for all samples was $45( \pm 21) \mathrm{cm}$ in the middle of gap, in $22( \pm 8) \mathrm{cm}$ at the sides of gap and $18( \pm 8) \mathrm{cm}$ under closed canopy. Comparing 2013 against 2014 , the height growth was mostly in the middle of the gap, where the height yield was $14 \mathrm{~cm}$. At the sides of the gap, height yield was $3 \mathrm{~cm}$, while under closed canopy it was only $1 \mathrm{~cm}$. While in 2013 there were significant differences between the heights of seedlings in the middle of the two gap, these differences were not significant in 2014; therefore, differences between gaps decreased in the two years of the research. 


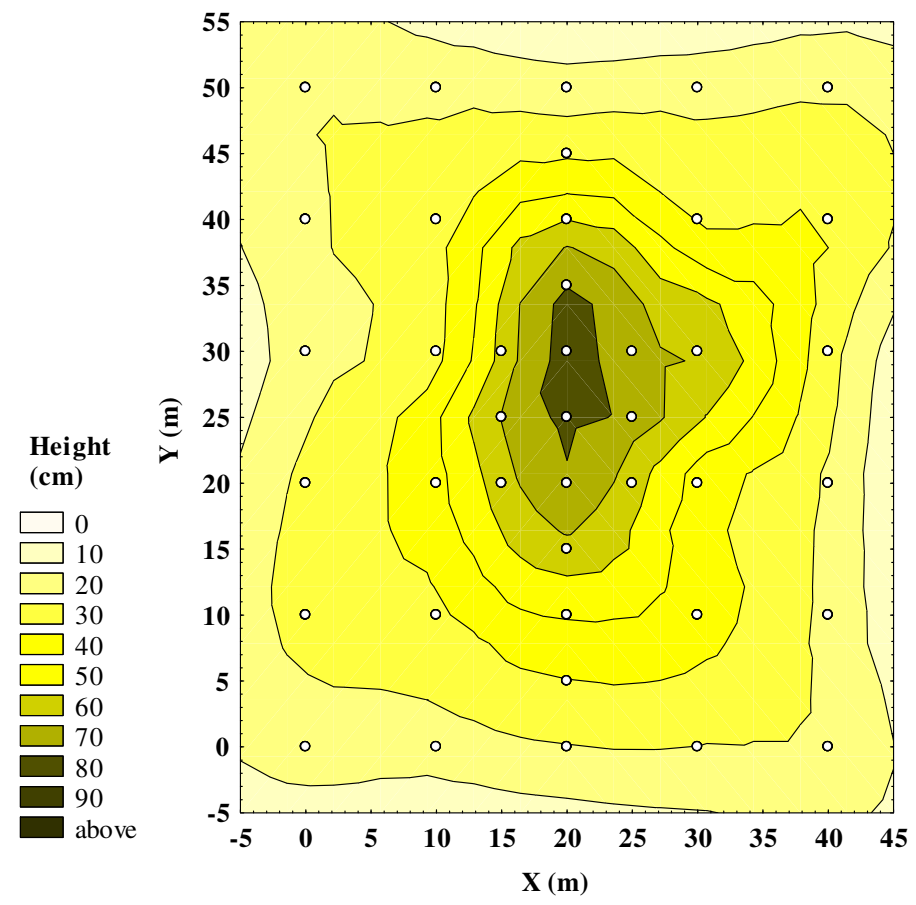

Figure 9. Vép 32/D, north-south gap, vertical distribution in 2014 of Turkey oak (Quercus cerris) seedlings

The vertical distribution (height) of seedlings in Figure 9 shows similar centralised symmetry as openness or soil moisture.

\subsection{Vegetation cover}

The dominant species in the Bejcgyertyános site in order of coverage were pokeweed (Phytolacca americana), common nettle (Urtica dioica), blackberry (Rubus fruticosus), giant goldenrod (Solidago gigantean), and bush grass (Calamagrostis epigeios).

In the Vép site, blackberry (Rubus fruticosus), giant goldenrod (Solidago gigantean), and bush grass (Calamagrostis epigeios) were the dominant species.

In the case of these species, it is a constant pattern that the greatest cover is in the middle of the gap, while the cover of herbs decreases rapidly closer to the closed canopy forest stand. Figure 10 shows the average total herb cover in 2014.

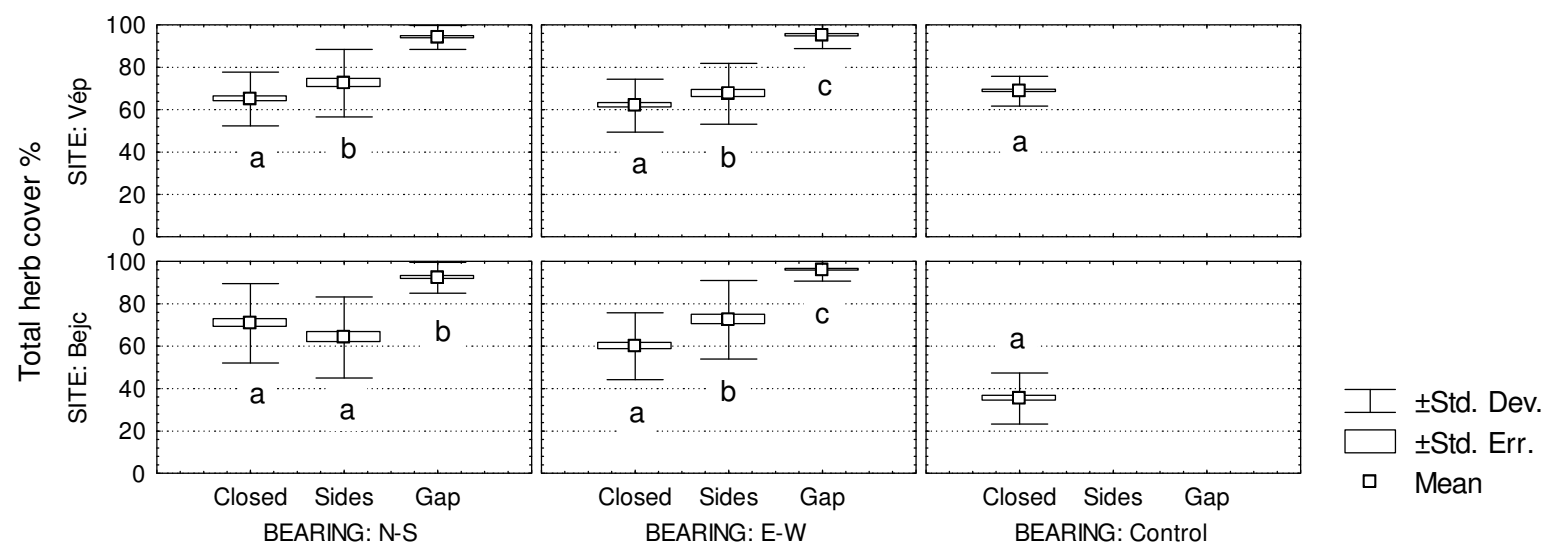

Figure 10. Average total herb cover in 2014,

different letters indicate significant differences $(p<0.05)$ between means inside a parcel 
Vegetation cover shows a very disperse pattern in the sites, and because of unknown parameters (such as the long lasting history of the forest stand before gap opening), sometimes it is inexplicable why species appear somewhere or not, or how much cover percentage a given species has.

In the case of vegetation cover, the control parcel in Bejcgyertyános has significantly less total cover than the closed canopy gap regions; therefore, in that variable, parcels should also be greater, as in the case of light conditions.

\subsection{Correlations}

In correlation analyses, the two sites and different years were separately tested (Table 2).

Table 2. Correlation matrix; red marked correlations are significant at $p<0.05$, VWC: Volumetric Water Content

\begin{tabular}{|c|c|c|c|c|c|c|c|c|}
\hline \multirow[b]{2}{*}{ Variable } & \multicolumn{4}{|c|}{ Bejcgyertyános 13 A } & \multicolumn{4}{|c|}{ Vép 32 D } \\
\hline & 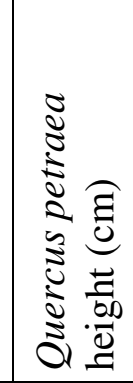 & 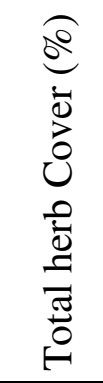 & 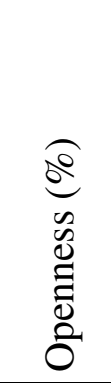 & 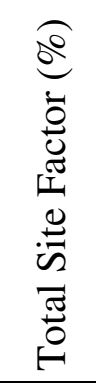 & 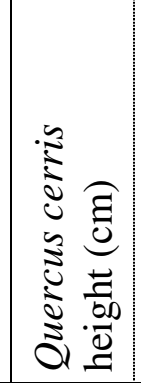 & 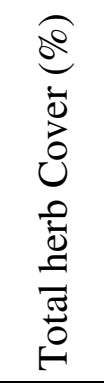 & $\begin{array}{l}\widehat{d} \\
\infty \\
0 \\
0 \\
0 \\
0 \\
0\end{array}$ & 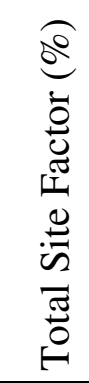 \\
\hline Year: 2013 & $\mathrm{~N}=141$ & \multicolumn{3}{|c|}{$\mathrm{N}=392$} & $\mathbf{N}=384$ & \multicolumn{3}{|c|}{$\mathrm{N}=392$} \\
\hline $\begin{array}{l}\text { Beginning of vegetation } \\
\text { season }\end{array}$ & 0.30 & 0.59 & 0.59 & 0.31 & 0.44 & 0.59 & 0.65 & 0.32 \\
\hline Drought period & 0.20 & 0.61 & 0.59 & 0.19 & 0.53 & 0.58 & 0.64 & 0.33 \\
\hline End of vegetation season & 0.39 & 0.68 & 0.72 & 0.47 & 0.57 & 0.61 & 0.69 & 0.51 \\
\hline Openness (\%) & 0.45 & 0.72 & & 0.72 & 0.66 & 0.66 & & 0.82 \\
\hline Total Site Factor (\%) & 0.49 & 0.49 & 0.72 & & 0.54 & 0.43 & 0.82 & \\
\hline Year: 2014 & $\mathrm{~N}=93$ & \multicolumn{3}{|c|}{$\mathrm{N}=392$} & $\mathbf{N}=384$ & \multicolumn{3}{|c|}{$\mathrm{N}=392$} \\
\hline $\begin{array}{l}\text { Beginning of vegetation } \\
\text { season }\end{array}$ & 0.40 & 0.67 & 0.75 & 0.47 & 0.52 & 0.67 & 0.70 & 0.40 \\
\hline Drought period & 0.11 & 0.66 & 0.71 & 0.33 & 0.61 & 0.62 & 0.69 & 0.43 \\
\hline End of vegetation season & 0.35 & 0.60 & 0.69 & 0.41 & 0.53 & 0.64 & 0.67 & 0.45 \\
\hline Openness (\%) & 0.50 & 0.70 & & 0.75 & 0.64 & 0.69 & & 0.75 \\
\hline Total Site Factor (\%) & 0.51 & 0.51 & 0.75 & & 0.52 & 0.50 & 0.75 & \\
\hline
\end{tabular}

The correlations were significant at almost every analysed pair of variables; therefore, a gap had demonstrable effect on the variables, but at a different scale. Openness has greater correlation with VWC of any period or total herb cover than total site factor; therefore, the slight northward light effect has less importance than the actual gap opening in those variables. In the case of regeneration height, the correlation with soil moisture and light is high in Vép where greater regeneration numbers are at the site; the greatest correlations were with openness. These correlations are slightly fewer in Bejcgyertyános; openness has no greater correlation than Total Site Factor, probably because fewer data exist. 


\section{CONCLUSIONS}

The paper summarizes the results of a two-year intensive mapping of various bearing artificial gaps at two sites in western Hungary: a sessile-oak-hornbeam, and a Turkey oak forest. The short observation period and small number of sites and parcels made it difficult to compare the results. However, there are significant differences in soil moisture, regeneration, and herb coverage between the middle of a gap and the closed canopy forest stands.

The results suggest that in the case of Turkey oak (Quercus cerris) forests, the openness of a gap show great importance as a determining factor. As an initial step of natural regeneration, the gap size used in the experiment should be enough to start a natural regeneration if there were sufficient seedlings or acorns during the time of gap opening. The orientation of the gap shows less importance in the research sites in the studied period.

If no seedlings were present at the time of the gap opening, as in case of sessile-oakhornbeam forests, the scattering of acorns would be minimal into the middle of a half-tree wide gap and herbs would colonise the gap.

It is also an important fact that even in drier forest stands, like the Vép 32/D site, gaps became significantly watered. This promotes the colonization of soil moisture indicator herbs species and other competitors. For all samples in the research period, the mean value of Volumetric Water Content (soil moisture) during the vegetation period in the sites was about 6 percentage points higher in the middle of a gap (29\%) than at the sides of it (23\%). The soil moisture was a further 2 percentage points lower under closed canopy $(21 \%)$.

Correlation analyses reveal that soil moisture, the height of regeneration, and the summarized cover of vegetation depended mostly on openness, and only slightly on the total site factor; therefore, the slight northward light effect of a gap under the closed canopy has less importance in a flat area than in the case of beech (Fagus sylvatica) forests in mountainous areas.

\section{APPENDIX}

Analysed depths were changed several times in 2013 with Field Scout TDR 300 Soil Moisture Meter with default calibration for standard soils. Comparison measurements were taken to standardise the data in 2014 from spring till summer in Bejcgyertyános 13/A forest subcompartment control parcel, when in 8 constant control grid point measurements were taken with all used rod lengths $(20 \mathrm{~cm}(\mathrm{n}=194), 12 \mathrm{~cm}(\mathrm{n}=224), 7.6 \mathrm{~cm}(\mathrm{n}=224))$ in all soil moisture conditions (moist to dry). The standard soil depth for analysis was defined as $7.6 \mathrm{~cm}$ because most of the measurements were in that depth; based upon this, the other rod length measurements were converted with converter equations. Volumetric Water Content data with depths of $20 \mathrm{~cm}$ and $12 \mathrm{~cm}$ were paired with $7.6 \mathrm{~cm}$ deep data, and these results were plotted in a diagram. Trend lines were fitted for these pairs to receive the best fitted function $\left(\mathrm{R}^{2}\right.$, and equations). The final converter equations (power function) are shown in Figure 11. In the upper level $(7.6 \mathrm{~cm})$, the soil is moister than the lower levels $(12 \mathrm{~cm}$ and $20 \mathrm{~cm})$, but there were no significant differences in the soil moisture in the lower levels. 


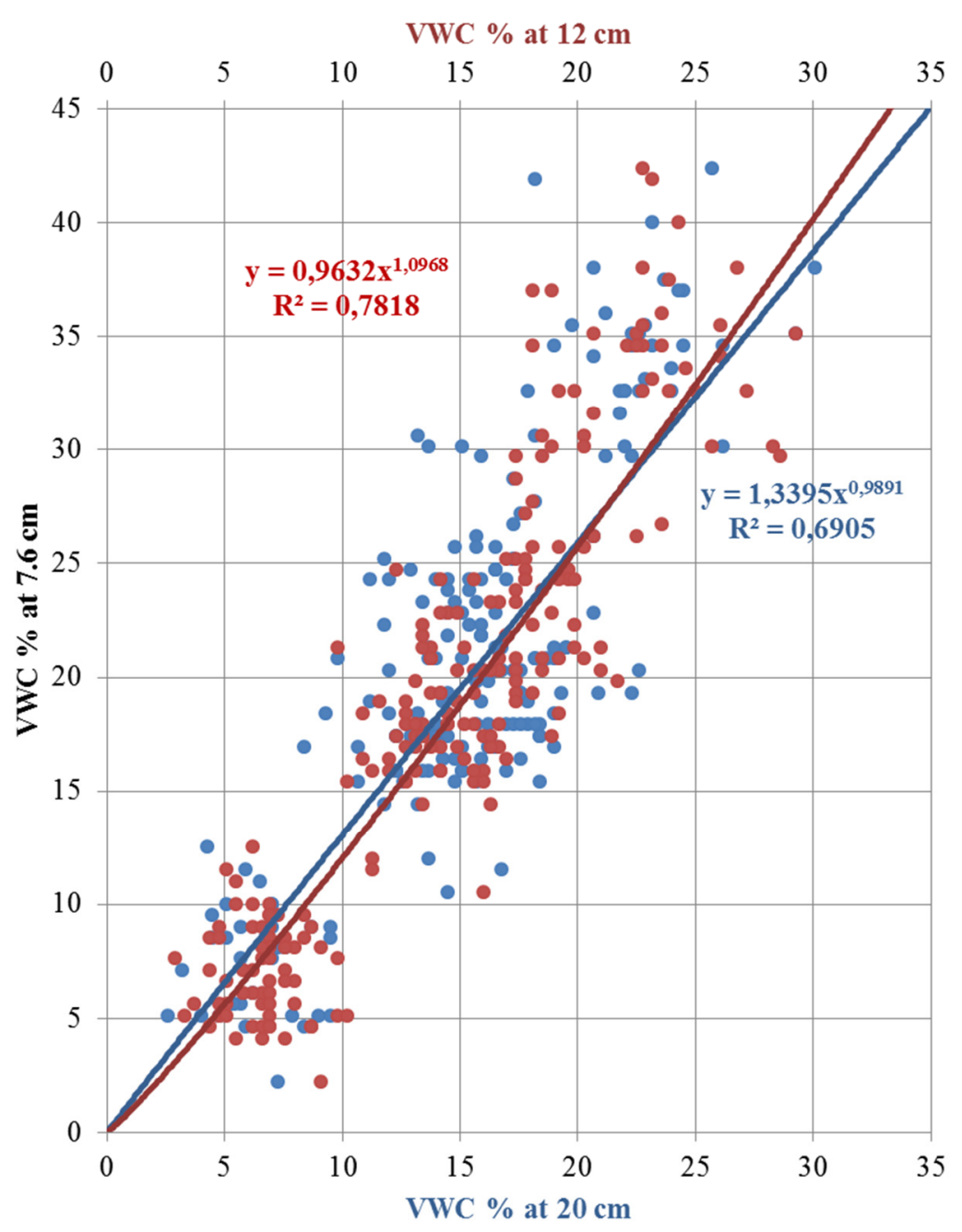

Figure 11. Converting equations of different Volumetric Water Content (VWC) data from $20 \mathrm{~cm}$ and $12 \mathrm{~cm}$ to $7.6 \mathrm{~cm}$ rod length used with Field Scout TDR 300 Soil Moisture Meter with default calibration for standard soils

Acknowledgements: First of all, I am grateful for the altruistic assistance of the publisher's reviewers without whom this article could not have been finished.

I also would like to thank Szombathely Forestry Corporation for providing the forest stands for my research. Finally, I would like to thank my colleagues for their help. This study was supported by the Silva naturalis - Investigation of continuous forest cover in ecological, conservational biological, public welfare and nature conservational aspects TAMOP-4.2.2.A11/1/KONV-2012-0004 project sponsored by the EU and the European Social Foundation.

\section{REFERENCES}

AiKens, M.L. - Ellum, D. - MCKenNA, J.J. - Kelty, M.J. - Ashton M. S. (2007): The effects of disturbance intensity on temporal and spatial patterns of herb colonization in a southern New England mixed-oak forest. Forest Ecology and Management 252: 144-158.

Bodonczi, L. - Illés, G. - Keresztes, GY. - MARghescu, T. - Meggyesfalvi, I. - SinKa, A. (2006): Selection cutting. HM Budapest Forestry Company, Budapest 
BROWN, N. (1996): A gradient of seedling growth from the centre of a tropical rainforest canopy gap. Forest Ecology and Management 82: 239-244.

BRUNNER, A. (2002): Hemispherical photography and image analysis with hemIMAGE and Adobe Photoshop. Danish Forest and Landscape Research Institute

CATER, M. - DiACI, J. - ROZENBERGAR, D. (2014): Gap size and position influence variable response of Fagus sylvatica L. and Abies alba Mill. Forest Ecology and Management 325: 128-135.

CLINTON, B.D. (2003): Light, temperature, and soil moisture responses to elevation, evergreen understory, and small canopy gaps in the southern Appalachians. Forest Ecology and Management 186: 243-255.

CSÉPÁNYI, P. (2008): A tölgy és a folyamatos erdőborítás [The oak and the continuous forest cover]. Erdészeti Lapok 143 (10): 294-297. (in Hungarian)

D'OlIVEIRA, M.V.N. - RIBAS, L.A. (2011): Forest regeneration in artificial gaps twelve years after canopy opening in Acre State Western Amazon. Forest Ecology and Management 261: 1722-1731.

FRAZER, G.W. - CANHAM, C.D. - LERTZMAN, K.P. (1999): Gap Light Analyzer (GLA), Version 2.0: Imaging software to extract canopy structure and gap light transmission indices from true-colour fisheye photographs, user's manual and program documentation. Simon Fraser University, Burnaby, British Columbia, and the Institute of Ecosystem Studies, Millbrook, New York

GAGNON, J. L. - JOKEL, E. J. - MOSER, W. K. - HUBER, D. A. (2004): Characteristics of gaps and natural regeneration in mature longleaf pine flatwoods ecosystems. Forest Ecology and Management 187: 373-380.

GÁlHIDY, L. - MiHÓK, B. - HAGYÓ, A. - KELEMEN, K. - RUFF, J. (2005): Felújulás egy bükkállomány mesterséges lékjeiben - a lékméret hatása az újulat változásaira [Regeneration in a beech stand's artificial gaps - the influence of gap size to the change of regrowth]. Erdészeti Lapok 140 (12): 358-361 (in Hungarian)

GÁLHIDY, L. - MiHÓK, B. - HAGYÓ, A. - RAJKAI, K. - STANDOVÁR, T. (2006): Effects of gap size and associated changes in light and soil moisture on the understorey vegetation of a Hungarian beech forest. Plant Ecology 183: 133-145.

GUAY, R. (2012): WinScanopy 2013a for canopy analysis, user's manual. Regent Instruments Canada Inc.

KOLLÁR, T. (2013): Lékek fényviszonyainak vizsgálata hemiszférikus fényképek segítségével [Investigation of light conditions of gaps with the aid of hemispherical photography]. Erdészettudományi Közlemények 3 (1): 71-78. (in Hungarian)

KoloszÁR, J. (2005): Szálalási lehetőségek és tudományos megalapozásuk [Selection cutting opportunities and its groundings]. In: Solymos, R. (eds.): Erdő- és fagazdaságunk időszerü kérdései. MTA Budapest: 307-311. (in Hungarian)

MANNINGER, M. (2008): Meteorológiai mérések a Bükkben [Meteorological measurements in Bükk]. Zárójelentés GVOP-3.1.1-2004-05-0190, Budapest (in Hungarian)

NAAF, T. - WULF, M. (2007): Effects of gap size, light and herbivory on the herb layer vegetation in European beech forest gaps. Forest Ecology and Management 244: 141-149.

PAgE, L. M. - CAMERON, A. D. (2006): Regeneration dynamics of Sitka spruce in artificially created forest gaps. Forest Ecology and Management 221: 260-266.

Petritan, A.M. - Nuske, R.S. - PetritAn, I.C. - Tudose, N.C. (2013): Gap disturbance patterns in an old-growth sessile oak (Quercus petraea L.) - European beech (Fagus sylvatica L.) forest remnant in the Carpathian Mountains, Romania. Forest Ecology and Management 308: 67-75.

PRO SILVA Principles [Pro Silva alapelvek] (1999): http://www.prosilva.hu/alapelvek.php (in Hungarian)

REININGER, H. (2010): A szálalás elvei, avagy a korosztályos erdők átalakítása [The principles of selection cutting or the transformation of even aged forests]. HM Budapest Erdőgazdaság Zrt., Budapest (in Hungarian)

RITTER, E. - DALSGAARD, L. - EINHORN, K. S. (2005): Light, temperature and soil moisture regimes following gap formation in a semi-natural beech-dominated forest in Denmark. Forest Ecology and Management 206: 15-33.

ROTH, GY. (1935): Erdőmüveléstan I, II. [Silviculture I, II]. Rottig - Romwalter Nyomda bérlői, Sopron. (in Hungarian) 
SOLYMOS, R. (2000): Erdőfelújítás és -nevelés a természetközeli erdőgazdálkodásban [Forest regeneration and -tending in the close-to-nature forest management]. Mezőgazdasági Szaktudás kiadó, Budapest (in Hungarian)

SPECTRUM TECHNOLOGIES INC. (2009): Field Scout TDR 300 Soil Moisture Meter, Product manual

TOBISCH, T. (2010): Gap-phase Regeneration of a Central-European Sessile Oak-Hornbeam Forest. South-east Eur for 1 (1): 28-40.

TÖRÖK, A. (2006): Bükkösök erdőfelújítása az égtájorientált felújítási rendszer tükrében [Regeneration of Beech forests in the aspect of exposure orientated regeneration system]. Bakonyerdő Erdészeti és Faipari Zrt., Veszprém (in Hungarian)

VAN DAM, O. (2001): Forest filled with gaps. Effects of gap size on water and nutrient cycling in tropical rain forest. A study in Guyana, PhD Dissertation, Utrecht University, Netherlands 